\title{
Development of Cardamom Herbal Coffee Beverages: A study of Physicochemical Characteristics and Consumer Perception Towards Sensory Properties
}

\author{
Noor Ariefandie Febrianto ${ }^{1 *}$, Viki Maulina Rizki ${ }^{2}$, and Djumarti ${ }^{2)}$ \\ ${ }^{1)}$ Indonesian Coffee and Cocoa Research Institute, Jl. PB Sudirman No. 90, Jember 68118, Indonesia \\ ${ }^{2)}$ Faculty of Agricultural Technology, Jember University, J1. Kalimantan No. 37, Jember 68121, Indonesia \\ ${ }^{*}$ Corresponding author: noor.ariefandie@gmail.com
}

\begin{abstract}
Herbal coffee is one of the coffee diversification products that has been well recognized in the market. Addition of herbs or spices in coffee, not only offer an enhanced flavor characteristic, but more importantly also offer the consumer to gain a health benefit. Cardamom (Amonum cardomum) is commonly recognized as a herb and a food spice to add flavor to dishes. This research was aimed to develop a herbal coffee containing the extract of cardamom and to study the characteristics of herbal coffee obtained physicochemically and by sensory analysis. Crystallized coffee and sugar mixture was blended with cardamom extracts $10 \%$, $20 \%, 30 \%, 40 \%$, and $50 \%$ to obtain ready to drink cardamom herbal coffee. The mixtures and control (without addition of cardamom) were then subjected for consumer perception by testing it to 30 panelists based on hedonic sensory test. The three mixtures that were choosen were then analysed for its physicochemical characteristics such as its powder and brewing appearrance, insoluble solids, reducing sugar and caffein concentration. The result showed that the addition of $10 \%, 20 \%$, and $30 \%$ cardamom extract had good preferences to consumer, which $10 \%$ of addition resulted the highest preferences. The hedonic sensory test resulted the preferences of the afore mentioned herbal coffee on color, aroma, taste and flavor was $3.37 ; 3.14 ; 3.30 ; 3.27$; and 3.37 (on scale 1 to 5 ), respectively, representing moderately like to like preferences.The physicochemical analysis showed that the mixture contained $0.17 \%$ of insoluble solid, $0.13 \%$ of reducing sugar and $0.45 \%$ caffeine which comply the Indonesia standard of SNI 4446:1998. This result showed that the cardamom herbal coffee is potential to be developed as one of coffee diversification products.
\end{abstract}

Keywords: coffee mix, herbal, cardamom, coffee diversification

\section{INTRODUCTION}

Coffee is one of the most popular beverage consumed in Indonesia. In addition to the varians of coffee products such as black coffee, 2 in 1, and 3 in 1 which is composed either by coffee, sugar, milk or creamer, the herbal coffee varian is also very popular. Herbal coffee is a common term to define the coffee product that has been enriched with herbs or spices such as ginger, pasak bumi (Eurycoma longifolia), panax (from the genus of Panax L.), Habbatussauda (black cumin/black seed/ Nigella sativa) and other herbs or spices. The enrichment of herb on coffee not only 
to improve the acceptance of the coffee itself, but more importantly also improve the nutritional value of it. Herbal coffee is also recognized as nutritionally enriched coffee due to the report that stated that the the combination of caffeine and herbal supplement had more effective effect for enhancing metabolic rates than consuming caffeine alone (Dullo et al., 1999; Roberts et al., 2005). The other herbal supplement that has been used in coffee varied from bitter orange (Citrus aurantium) that has been used to treat digestive problem to Garcinia cambogia that has been used to solve the obesity issues (Hoffman et al., 2006).

Cardamom (Amomum cardamomum) is recognized as "false" cardamom compared to Elettaria cardamomum ("true" cardamom) due to its lower content of essential oil (Santoso, 2006). However, this "false" cardamom is still commonly used as spice to enhance the flavor of the dishes in several countries such as India and Indonesia. Cardamom has been known to contain a wide variety aromatic compounds such as $\alpha$-terpineol, myrcene, subinene, limonene, cineol, $\alpha$-phellandrene, menthone, cis/ translinalol oxides, $\alpha$ and $\beta$ pinene, eugenyl acetate, phytol, borneol, citronellol, bisabolene, p-cymene, geranyl acetate, geraniol, stigmasterol and terpinene (Shaban et al., 1987; Noleau et al., 1987; Gopalakrishnan et al., 1990; Duke, 1992). According to Syukur \& Hernani (2001) and Rosjidi (1993), sineol is the main aromatic compounds in "false" cardamom which compromise approximately $12 \%$ of the weight. This compound gives sharp cool, pungent, a little bit spicy and has refreshing sensation; the taste of the cardamom itself represent the taste of pepper or ginger-like sensation (Rosjidi, 1993).

Cardamom also has been used as traditional medicine for tonsil and throat inflammation, stomach ache, asthma, fever and fatigue reliever. On the other hand, it can also be used for influenza, rheumatic, and cough treatment (Indo, 1993). In vitro studies of cardamom also showed that cardamom could reduce the blood pressure in rats (Iyer et al., 2009), and possess antioxidant, anti hypertensive, gastroprotective, anti bacterial, and anticancer properties (Verma et al., 2009). Previous findings also showed that cardamom exert immunomodulatory and antitumor activity and can promote the maintenance of healthy immune system (Majdalawieh \& Carr, 2010). This research was aimed to develop a herbal coffee containing the extract of cardamom and to study the characteristics of herbal coffee obtained physicochemically and by sensory analysis.

\section{MATERIALS AND METHODS}

The Robusta coffee powder was obtained from Indonesian Coffee and Cocoa Research Institute (ICCRI), Jember, East Java. Meanwhile, the dried cardamom was obtained from local market. The research was conducted in Post-harvest Laboratory of ICCRI, Jember and Agriculture Product's Chemistry and Biochemistry Laboratory in Faculty of Agricultural Technology, Jember University, Jember, East Java.

The soluble coffee powder was prepared by brewing the Robusta coffee powder with hot water $\left(93-96^{\circ} \mathrm{C}\right)$ with the ratio powder to water was 1 to $4(1: 4 \mathrm{w} / \mathrm{v})$. The mixtures was then homogenized using stirrer and filtered using muslin cloth. The filtrate was then added with cane sugar with the ratio of $1: 2(\mathrm{w} / \mathrm{v})$. The crystallization process was carried out by evaporating the solution in $100^{\circ} \mathrm{C}$ until crystallized. The crystal was then powdered and screened using 40 mesh sieve. The soluble coffee powder was then stored in dry place until used. 
The soluble cardamom extract powder was prepared by dehusking the dried cardamom until the seed was obtained. The cardamom seed was powdered by using kitchen blender. The powder was then screened using 80 mesh sieve until the fine cardamom powder obtained. The powder was then brewed with warm water $\left(57-60^{\circ} \mathrm{C}\right)$ for $30 \mathrm{~min}$ with the ratio powder to water was 1 to $4(1: 4 \mathrm{w} / \mathrm{v})$. The mixtures was then stirred until homogen and filtered using muslin cloth. The filtrate was then added with cane sugar with the ratio of $1: 2(\mathrm{w} / \mathrm{v})$ and continued to crystallization process carried out by evaporating the solution in $100^{\circ} \mathrm{C}$ until crystallized. The crystal was then powdered and screened using 40 mesh sieve. The cardamom extract powder was then stored in dry place until used.

Mixtures of cardamom herbal coffee powder were prepared in following proportions as mentioned in Table 1. Simple mixture design was used to determine the proportion of the factors (A: coffee powder and B: cardamom powder). The levels were in the range of $0 \%$ to $100 \%$ with the total mixture was $100 \%(\mathrm{~A}+\mathrm{B}=1)$. The coffee powder and cardamom powder was mixed until evenly distributed powder was obtained. For hedonic test, the powder was brewed using hot water prior to testing.

The hedonic test was carried out using 5 different attributes such as color, aroma, taste, flavor and overall acceptability. Thirty one grams of the mixture powder was brewed using $150 \mathrm{~mL}$ hot water. The measurement of panelist response was performed using 5 scale scoring consisting of 1 (very dislike), 2 (dislike), 3 (moderately like), 4 (like) and 5 (like very much). To avoid a bias, the identity of the samples analysed were randomized using 3 random numbers. The hedonic test was carried out by 30 panelists in triplicate. To choose the best formulation, the effectiveness index method by Degarmo et al. (1984) was employed. The effectiveness was determined using the weight to the value variable (BV) and weight of normal (BN) index. From the value obtained, the value of effectiveness $(\mathrm{Ne})$ was calculated using the formula below.

Value of effectivenes $=($ Treatment value-worst value)/(Best value-worst value)

The total value $(\mathrm{Nh})$ was calculated by multiplying the $\mathrm{BN}$ with $\mathrm{Ne}$. Two formulations with highest effectiveness index was then choosen for physicochemical analysis.

Insoluble solids content was analysed according the method described in Indonesian National Standard (BSN, 1992). Two point five grams of mixture powder was mixed with hot water until $250 \mathrm{~mL}$ in $600 \mathrm{~mL}$ beaker glass. After the solution was rested for 5 minutes, the solution was then filtered using a known weight dry filter paper. The precipitate that left in filter paper was washed several times using hot water until the filter paper was clean. The filter paper was then dried in $105^{\circ} \mathrm{C}$ for one hour and stored in desiccator until reached the constant weight. The filter paper was then weighted and calculated for total insoluble solid content. The analysis was done in triplicate.

The total reducing sugar was analysed using the method of Nelson-Somogyi (Sudarmadji, 1997), whereas the caffeine content was analysed using the method of AOAC (AOAC, 1984). The analysis was done in triplicate.

The statistical analysis was carried out using one way ANOVA on total insoluble solids, total reducing sugar and caffeine content results. The Duncan multiple range test was used as post-hoc analysis employing the software of SPSS Statistic Version 17 (SPSS Inc.). 


\begin{tabular}{lcc}
\hline \multirow{2}{*}{ Mixtures } & \multicolumn{2}{c}{ Proportion, $\%$} \\
\cline { 2 - 3 } & Soluble coffee powder (A) & Soluble cardamom powder (B) \\
\hline Control & 100 & 0 \\
Formula 1 & 90 & 10 \\
Formula 2 & 80 & 30 \\
Formula 3 & 70 & 40 \\
Formula 4 & 60 & 50 \\
\hline
\end{tabular}

\section{RESULT AND DISCUSSION}

\section{Hedonic test}

As presented in Figure 1, the panelist responses on the formulation of cardamom herbal coffee varied among the formulation. In general, all the formulation including control possessed the value of response in the range of 2.82 to 3.55 , represented the respons of "almost" moderately like to like preferences. The control (coffee powder without cardamom addition) possessed higher point in all variable compared cardamom herbal coffee except for the taste variable. This condition thus represent that the addition of cardamom powder significantly increase the taste acceptability of herbal coffee on panelists. The figure also shows that the addition of cardamom powder decreased the acceptance of panelist on color, aroma, flavor and its overall acceptability. The higher concentration of the cardamom powder resulted in the less acceptability of the herbal coffee. This phenomenom was also explained previously by Kemp et al. (2009) which mentioned that the score assigned to sample also could be influenced by the assessor's judgement which tend to find what they expect to find. In this case, when the sample was introduced and designated as "coffee" product, the panelist tend to use the coffee (without addition of cardamom) as the standard of their scoring.
As presented in Figure 1, the hedonic test responses between $10 \%$ cardamom and $20 \%$ cardamom show some similarity on the pattern of panelist responses. On the other hand, $30 \%$ cardamom, $40 \%$ cardamom and $50 \%$ cardamom were slightly different but also showed a similarity in lower values of the responses. The result of effectiveness index determination also concluded that the $10 \%$ and $20 \%$ cardamom had highest preferences among the panelists (Table 2) along with the control. The control coffee powder obtained 0.91 effectiveness index point, the highest value compared to the others. This result show that the panelist still generally preferred the "original" coffee compared to cardamom herbal coffee. This condition might be the result of unfamiliar sensation that was experienced by the panelist when tasting the cardamom herbal coffee. The addition of cardamom had significantly changed the color, aroma, taste and the flavor of the coffee, which made them brighter in color, sharper in aroma, cooler in sensation of taste and more herb-like in flavor due to the existence of sineol compound in cardamom (Rosjidi, 1993; Duke, 1992).

The major breakdown of cardamom addition on herbal coffee characteristics were in term of the aroma and the flavor. The addition of cardamom significantly decreased the preferences of herbal coffee to panelists. 


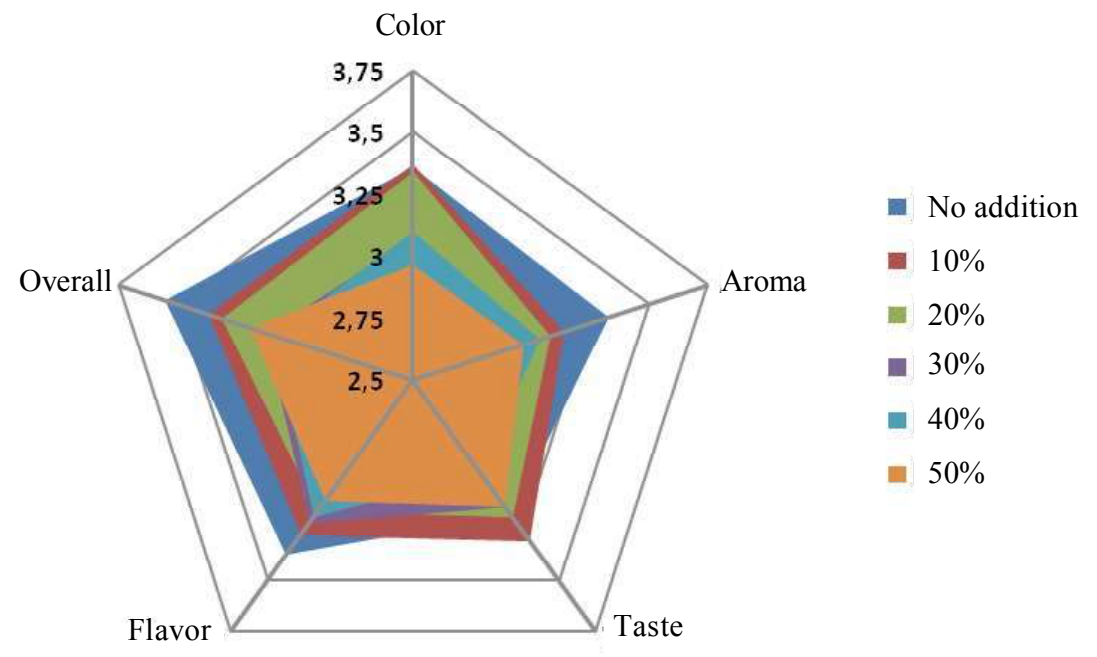

Figure 1. Scoring result of hedonic test of cardamom herbal coffee on different percetage of cardamom powder addition

The higher concentration of cardamom used in herbal coffee, the lower the responses of the panelists. Since the panelists was already familiar with original coffee, the addition of cardamom powder seemed to disturb their current perception of the coffee. Coffee aroma and flavor was contributed by numerous functions of the compounds, in which Flament (2002) resuming the identified compound responsible for coffee flavor from previous researches and found as much as about 648 functions. Flament (2002) and Buffo \& Cardelli-Freire (2004) also showed that hydrocarbons, ketones, phenols, furans and pyrans, thiophenes, pyrroles, oxazoles, thiazoles and pyrazines were the most identified cotributing compounds. On the other hand, aromatic volatiles compounds such as $\alpha$-terpineol, myrcene, subinene, limonene, cineol, $\alpha$-phellandrene, menthone, cis/trans-linalol oxides, $\alpha$ and $\beta$ pinene, eugenyl acetate, phytol, borneol, citronellol, bisabolene, p-cymene, geranyl acetate, geraniol, stigmasterol and terpinene which are commonly found in cardamom (Shaban et al., 1987; Noleau et al., 1987; Gopalakrishnan et al., 1990; Duke, 1992), are not exist or only minor in coffee. Thus, the addition of cardamom that possess a unique characteristic of aroma and mixed with coffee, it changed the original coffee aroma and flavor and gave an unusual perception of common coffee product. Even so, the addition of cardamom until $20 \%$ were still have a good preference to the panelist represented by its high effectiveness index for $10 \%$ and $20 \%$ cardamom addition which were 0.78 and 0.56 , respectively.

The physicochemical analysis was carried out on the selected sample $10 \%$ and $20 \%$ addition compared to the control. The analysis was done to characterize the insoluble solid content, reducing sugar content and caffeine content. The insoluble solids content of $10 \%, 20 \%$ and $30 \%$ cardamom addition was presented in Figure 2. The total insoluble solids (TIS) of selected cardamom herbal coffee of $0 \%, 10 \%$ and $20 \%$ cardamom 
Table 2. Effectiveness analysis of hedonic test result

\begin{tabular}{|c|c|c|c|c|c|c|c|}
\hline \multicolumn{2}{|c|}{ Formulation } & Color & Aroma & Taste & Flavor & Overall & Effectiveness index \\
\hline \multicolumn{2}{|l|}{ BV } & 0.95 & 1.00 & 1.00 & 0.90 & 0.90 & \\
\hline \multicolumn{2}{|l|}{$\mathrm{BN}$} & 0.20 & 0.21 & 0.21 & 0.19 & 0.19 & \\
\hline \multirow[t]{2}{*}{ F0 } & $\mathrm{Ne}$ & 0.97 & 1.00 & 0.62 & 1.00 & 1.00 & \\
\hline & $\mathrm{Nh}$ & 0.20 & 0.21 & 0.13 & 0.19 & 0.19 & 0.91 \\
\hline \multirow[t]{2}{*}{$\mathrm{F} 1$} & $\mathrm{Ne}$ & 1.00 & 0.63 & 1.00 & 0.63 & 0.62 & \\
\hline & $\mathrm{Nh}$ & 0.20 & 0.13 & 0.21 & 0.12 & 0.12 & 0.78 \\
\hline \multirow[t]{2}{*}{$\mathrm{F} 2$} & $\mathrm{Ne}$ & 0.92 & 0.51 & 0.65 & 0.22 & 0.49 & \\
\hline & $\mathrm{Nh}$ & 0.19 & 0.11 & 0.14 & 0.04 & 0.09 & 0.56 \\
\hline \multirow[t]{2}{*}{ F3 } & $\mathrm{Ne}$ & 0.28 & 0.00 & 0.50 & 0.41 & 0.09 & \\
\hline & $\mathrm{Nh}$ & 0.05 & 0.00 & 0.11 & 0.08 & 0.02 & 0.25 \\
\hline \multirow[t]{2}{*}{$\mathrm{F} 4$} & $\mathrm{Ne}$ & 0.33 & 0.43 & 0.00 & 0.30 & 0.00 & \\
\hline & $\mathrm{Nh}$ & 0.06 & 0.09 & 0.00 & 0.06 & 0.00 & 0.21 \\
\hline \multirow[t]{2}{*}{ F5 } & $\mathrm{Ne}$ & 0.00 & 0.29 & 0.50 & 0.00 & 0.22 & \\
\hline & $\mathrm{Nh}$ & 0.00 & 0.06 & 0.11 & 0.00 & 0.04 & 0.21 \\
\hline
\end{tabular}

addition were $0.24,0.14$ and $0.07 \%$, respectively.This research found that the addition of cardamom significantly change the total in soluble solid content of the coffee mixtures. This condition might happen due to the use of finely grounded Robusta coffee powder in this research that passed during sieving, which resembling the highest TIS in control. Meanwhile the soluble cardamom powder was proceeded from relatively coarse powder ( $80 \mathrm{mesh}$ ) of cardamom that resulted in lower TIS of soluble powder. Thus the addition of cardamom powder on the coffee mixtures would reduce the TIS content since it possessed lower TIS content.

The term of total insoluble solids might also referred as the "insolubility" of herbal coffee powder during the brewing process. Indonesian National Standard SNI (01-29831992) previously mentioned that the TIS content in instant coffee was limited at $0.25 \% \mathrm{w} / \mathrm{w}$. However, in new Indonesian National Standard which was published in 2014 (SNI 01-2983-2014), the TIS term has been excluded and changed into the term of "solubility". This term of "solubility" is not measured by the weight of insoluble solids of the powder but more to the ability of the powder to be solubilized by using hot and cold water in 30 seconds (BSN, $1992 ; 2014)$. Since the herbal coffee powder is the mixture of coffee and other materials, it also can be grouped and comply the requirement of traditional powdered beverage product standard (SNI 43201996) which limited the solubility of the beverages at minimum $75 \%$ (BSN, 1996). Previous research of Bachtiar (2011) found that the instant beverage's solubility was highly correlated to the acceptance of the consumer. He found that the beverage's solubility as high as $97.5 \%$ resulted in high acceptance by the panelists. On the other hand, the beverage's solubility as low as $78.3 \%$, $73.3 \%$ of the panelists gave low acceptance on the product.

The reducing sugar content of selected herbal coffee were $1.25,1.13$ and $0.92 \%$ (not significantly different), for control, 10\%, $20 \%$ and $30 \%$ cardamom addition, respectively (Figure 3). The analysis of reducing sugar content was done to measure the existence of monosaccharides and disaccharides in beverage powder. Since the making of 


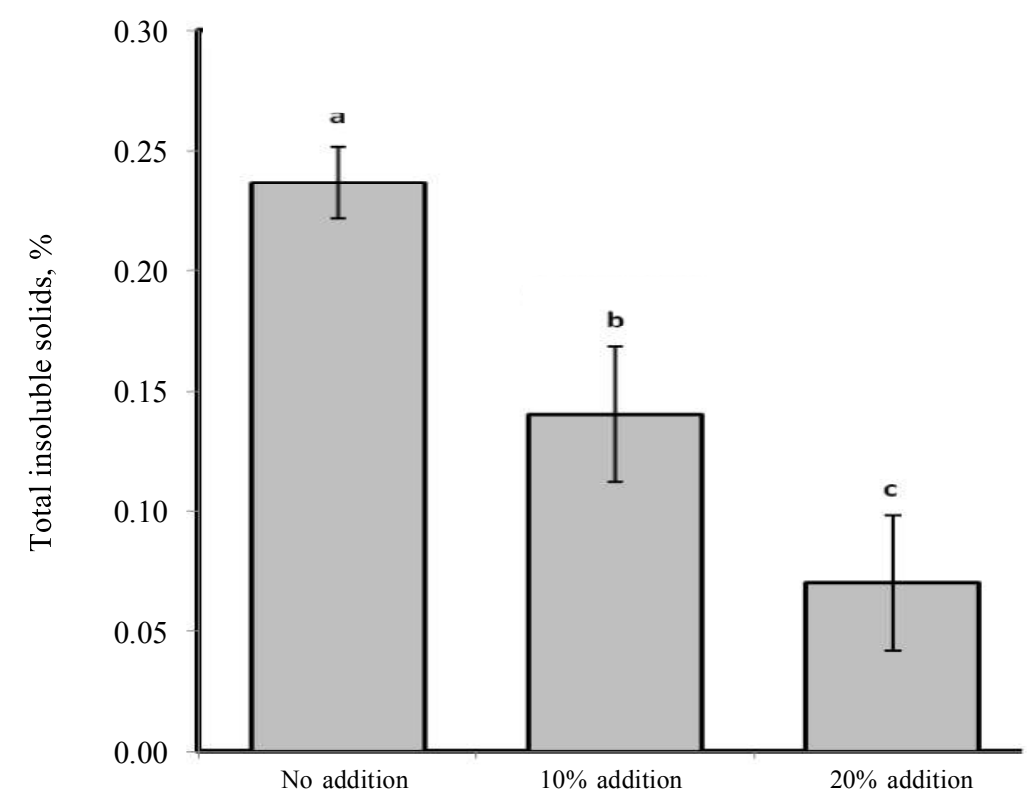

Figure 2. Total insoluble solids of the cardamom herbal coffee in different percentage of cardamom addition. Columns followed by the same letter are not significantly different at $\mathrm{P}<0.05$ according to Duncan multiple range test

soluble coffee and soluble cardamom powder only employed sugar (sucrose) which is not reducing sugar, the existence of reducing sugar is important to explain the sugar depolimerization occurred prior to consumption. Naturally, sucrose (non-reducing sugar) will be broken down into glucose and fructose (both are reducing sugar) during consumption by the activity of isomaltase glycoside hydrolases enzyme (Gray, 1971; Kaneko 2008). The existence of reducing sugar group in the beverages could lead to the browning process (Maillard reaction) when react with acidified protein. The more power and the amount of reducing sugar could lead into extensive non-enzymatic browning on the product.The existence of high concentration of reducing sugar will also reduce the metal ions when reacted and more susceptible to alkaline hydrolysis compared to nonreducing sugar (Wrolstad, 2012). The values of reducing sugar examined during this research were below $1.245 \%$, which comply the requirement of SNI 01-29831992 -instant coffee $(<10 \% \mathrm{w} / \mathrm{w})$ and SNI 01-2983-2014-instant coffee ( $\max 2.46 \%$ w/ w, as glucose).

On the other hand, the caffeine content of control, $10 \%$ and $20 \%$ cardamom addition were found to be $0.52,0.45$, and $0.39 \%$, respectively (Figure 4 ). These values were lower than the standard if refer to the SNI 01-2983-1992-instant coffee (2-8\%) and SNI 01-2983-2014-instant coffee ( $\min .2 .5 \%$ ). However, it complies the requirements of mix coffee beverages (SNI 01-4446-1998) (BSN, 1998). Because the cardamom used as the mixture of herbal coffee used in this experiment was high in volatiles, not in caffeine content, the addition of this compound significantly reduced the caffeine content of herbal coffee mixture due to the reduction of coffee powder used in the mixture. On the other hand, the soluble coffee used in this experiment was made 


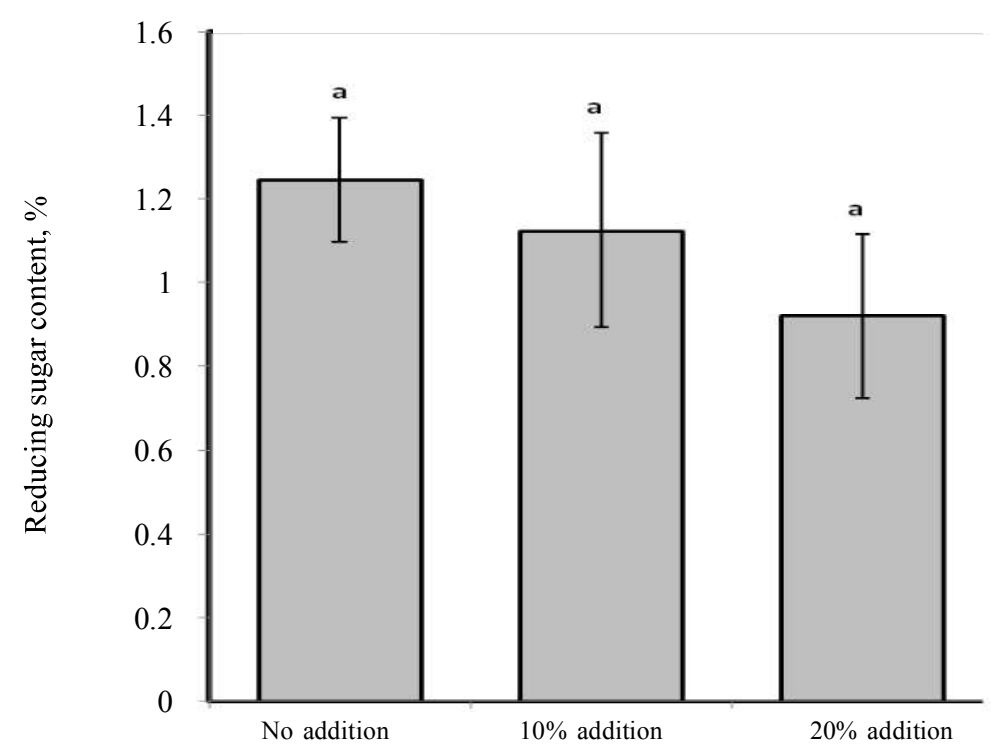

Figure 3. Reducing sugar content of the cardamom herbal cotfee in different percentage of cardamom addition

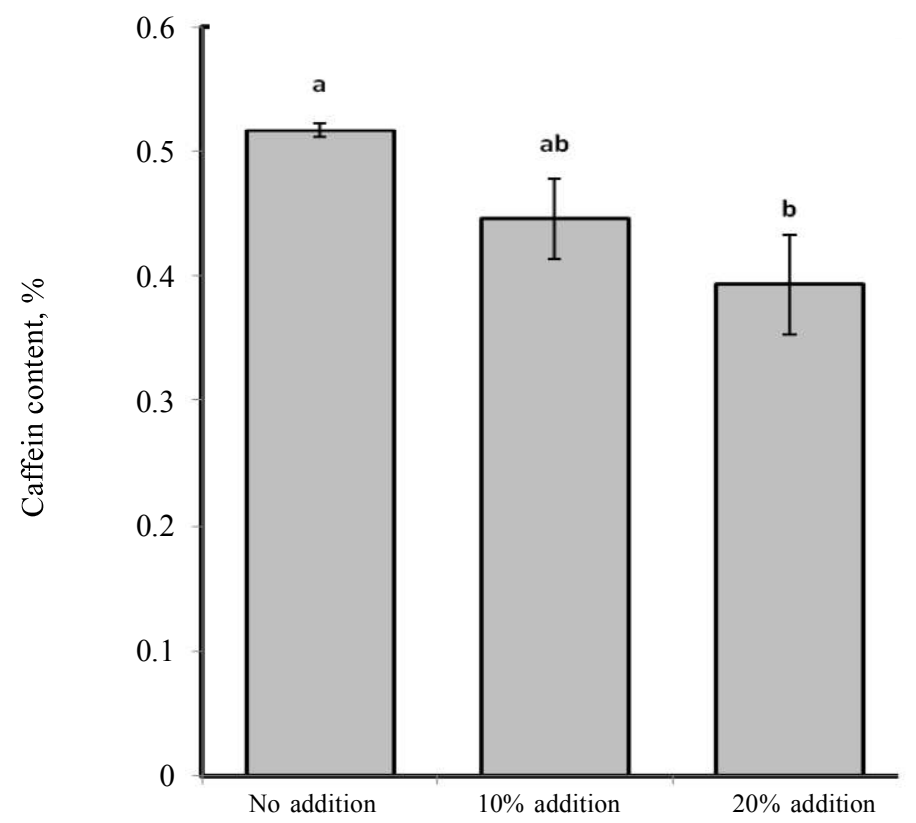

Figure 4. Caffeine content of the cardamom herbal coffee in different percentage of cardamom addition

by using high proportion of sugar (sugar : coffee filtrate ratio $=1: 2$ ) as crystallizing agent, was quite different with commercial instant coffee that utilized freeze drying or spray drying to directly powder the pure concentrate coffee filtrate (Farah, 2012). Thus it is well earned that the soluble coffee and its mixture of herbal coffee possesed low amount of caffeine due to the low proportion of coffee used. 


\section{CONCLUSION}

The cardamom herbal coffee product and formulation has been successfully developed in this experiment. The addition of cardamom instant powder significantly improve the characteristics of herbal coffee in term of taste characteristic and lower the attribute of color, aroma, flavor and overall acceptance of herbal coffee towards the panellist. The formulation of herbal coffee that consist of maximum $20 \%$ of cardamom instant powder found to give the best effectiveness index and acceptance by the panellist, whereas the addition of more cardamom powder resulted in less acceptance of herbal coffee. The addition of cardamom instant powder also significantly reduced the total insoluble solids content and the caffeine content of herbal coffee powder, but not significantly affected the reducing sugar content. These result concluded that the addition of cardamom instant powder up to $20 \%$ can be potentially applied as herbal coffee beverages as an option of coffee diversification products.

\section{REFFERENCES}

Ahmad, I.; T.. Hussain; I. Ashraf; M. Nafees; M.R. Maryam \& M. Iqbal (2013). Lethal effects of secondary metabolitas on plant tissue culture. Journal of Agricultura and Environmental Science, 13, 539-547.

AOAC (1984). Officials Methods of Analysis. Association of Official Analytical Chemists. Washington. D.C., USA.

Bachtiar, R. (2011). Pembuatan Minuman Instan Sari Kurma (Phoenix dactylifera). Bachelor thesis. Bogor Agricultural University. Bogor.

BSN, 1996.SNI 4320 (1996). Minuman dalam Kemasan. Badan Standardisasi Nasional. Jakarta. Indonesia.

BSN.1992. SNI 2983 (1992). Kopi Instan. Badan Standardisasi Nasional. Jakarta. Indonesia.
BSN. 1998.SNI 01-4446 (1998). Kopi Mix. Badan Standardisasi Nasional. Jakarta. Indonesia.

BSN. 2014.SNI 2983 (2014). Kopi Instan. Badan Standardisasi Nasional. Jakarta. Indonesia.

Buffo, R.A. \& C. Cardelli-Freire (2004). Coffee flavour: an overview. Flavour and Fragrance Journal, 19, 99-104.

De Garmo, E.D.; W.G. Sullivan \& J.R. Canada (1984). Engineering Economy. MacMillan Publishing Company, New York.

Duke, J.A. (1992). Handbook of Phytochemical Constituents of GRAS Herbs and other Economic Plants: Herbal Reference Library, pp. 239-240, CRC Press, London.

Dulloo, A.G.; C. Duret; D. Rohrer; L. Girardier; N. Mensi; M. Fathi \& P. Chantre (1999). Efficacy of a green tea extract rich in catechin polyphenols and caffeine in increasing 24-h energy expenditure and fat oxidation in humans. American Journal of Clinical Nutrition, 70, 1040-1045.

Farah, A. (2012). Coffee Constituents. In Coffee: Eerng Health Effects and Disease Prevention. Chu, YF. Ed. John Wiley \& Sons, Inc. New York. USA.

Flament, I. (2002). Coffee Flavor Chemistry. John Wiley \& Sons, Inc. New York. USA.

Gopalakrishnan, M.; C.S. Narayanan \& M. Grenz (1990). Non saponifible lipid constituent of cardamom. Journal of Agriculture and Food Chemistry, 38, 2133-2136.

Gray, G.M. (1971). Intestinal digestion and maldigestion of dietary carbohydrate. Annual Review of Medicine, 22, 391-404.

Hoffman, J.R.; J. Kang; N.A. Ratamess; P.F. Jennings; G. Mangine \& AD. Faigenbaum (2006). Thermogenic effect from nutricially enriched coffee consumption. Journal of the International Society of Sports Nutrition, 3, 35-41. 
Indo, A.M. (1993). Kapulaga: Budidaya, Pengolahan dan Pemasaran. Penebar Swadaya. Jakarta.

Iyer, A.; S. Panchal; H. Poudyal \& L. Brown (2009). Potential health benefits of Indian spices in the symptoms of the metabolic syndrome: A review. Indian Journal of Biochemistry and Biophysics, 46, 467-481.

Kaneko, J.J. (2008). Carbohydrate metabolism and its diseases. p. 46. In: J.J. Kaneko, J.W. Harvey \& M.L. Bruss (Eds.) Clinical Biochemistry of Domestic Animals, San Diego, CA: Academic Press.

Kemp, S.E.; T. Hollowood \& J. Hort (2009). Sensory Evaluation a Practical Handbook. A John Wiley \& Sons, Ltd. Singapore.

Majdalawies, A.F. \& R.I. Carr (2010). In vitro investigation of the potential immunomodulatory and anti-cancer activities of black pepper (Piper nigrum) and cardamom (Elettaria cardamo-mum). Journal of Medicinal Food, 13, 371-381.

Noleau, I.; B. Toulemonde \& H. Richard (1987). Volatile constituent of cardamom Elettaria cardamomum Maton cultivated in Costa Rica. Flavour and Fragrance Journal, 2, 123-127.

Roberts, A.T.; L. de Jonge-Levitan; C.C. Parker \& F.L. Greenway (2005). The effect of an herbal supplement containing black tea and caffeine on metabolic parameters in humans. Alternative Medicine Review, 10, 321-325.
Rosjidi, I. (1993). Pengaruh Tingkat Kesegaran dan Ukuran Bahan serta Lama Penyulingan terhadap Mutu dan Rendemen Minyak Kapulaga Lokal (Amomumcardamomum wild.). Bachelor thesis. Bogor Agricultural University. Bogor.

Santoso, H.B. (2006). Kapulaga. Penerbit Kanisius. Yogjakarta.

Shaban, M.A.E.; K.M. Kandeel; G.A. Yacout \& S.E. Mehaseb (1987). The chemical composition of the volatile oil of Elettaria cardamomum seeds. Pharmazie, 42, 207-208.

Sudarmadi, S.; B. Haryono \& Suhardi (1997). Prosedur Analisa utuk Bahan Makanan dan Pertanian. Jogjakarta : Liberty.

Syukur, C. \& Hernani (2001). Budidaya Tanaman Obat Komersial. Penebar Swadaya. Jakarta.

Verma, S.K.; V. Jain \& S.S. Katewa (2009). Blood pressure lowering, fibrinolysis enhancing and antioxidant activities of cardamom (elattaria cardamomum). Indian Journal of Biochemistry and Biophysics, 46, 503-506.

Verma, S.K.; V. Jain \& S.S. Katewa (2009). Blood pressure lowering, fibrinolysis enhancing and antioxidant activities of cardamom (elattaria cardamomum). Indian Journal of Biochemistry and Biophysics, 46, 503-506.

Wrolstad, R.E. (2012). Food Carbohydrate Chemistry. John Wiley and Sons, Inc. New York.

$* * 0 * *$ 